\title{
VEGETATION DIVERSITY ON THE MICROSITES CAUSED BY TREE UPROOTING DURING A CATASTROPHIC WINDTHROW IN TEMPERATE BROADLEAVED FORESTS
}

\section{G. Khanina}

Institute of Mathematical Problems of Biology of the Russian Academy of Sciences - branch of the M. V. Keldysh Institute of Applied Mathematics of the Russian Academy of Sciences, 1 Prof. Vitkevich street, Pushchino, 142290, Russia E-mail: khanina.larisa@gmail.com

\section{V. Bobrovsky}

Institute of Physico-Chemical and Biological Problems in Soil Sciences of the Russian Academy of Sciences, 2 Institutskaya street, Pushchino, 142290, Russia

E-mail: maxim.bobrovsky@gmail.com

\section{V. Zhmaylov}

Russian Forest Museum, 45th Monetchikovsky lane, Moscow, 115054, Russia

E-mail:ulmus@yandex.ru

\section{РАЗНООБРАЗИЕ РАСТИТЕЛЬНОСТИ НА ЭЛЕМЕНТАХ ВЕТРОВАЛЬНО-ПОЧВЕННЫХ КОМПЛЕКСОВ НА УЧАСТКАХ КАТАСТРОФИЧЕСКОГО ВЕТРОВАЛА В ШИРОКОЛИСТВЕННЫХ ЛЕСАХ}

\section{Л. Г. Ханина}

Институт математических проблем биологии РАН - филиал Института прикладной математики им. М. В. Келдыша РАН, Россия, 142290, Пущино, ул. проф. Виткевича, 1 E-mail: khanina.larisa@gmail.com

\section{М. В. Бобровский}

Институт физико-химических и биологических проблем почвоведения РАН - обособленное подразделение ФИЦ ПНЦБИ РАН, Россия, 142290, Пущино, ул. Институтская, 2

E-mail: maxim.bobrovsky@gmail.com

\section{И. В. Жмайлов}

Федеральное бюджетное учреждение «Российский музей леса», Россия, 115054, Москва, 5-й Монетчиковский пер., д. 4 E-mail:ulmus@yandex.ru

Abstract. We analyzed the diversity of vascular plant species growing on microsites formed after tree falls with uprooting as a result of catastrophic windthrow that occurred in the temperate broadleaved forests of the Kaluzhskie Zaseki Reserve in 2006. Size characteristics of pits and mounds formed by uprooting of 110 individuals of 9 tree species were measured. Vegetation on microsites formed by 45 fallen trees of 8 species was described. We distinguished the following microsites: 1) top of the mound; 2) back side of the mound; 3) front side of the mound (from the trunk side); 4) pit over the mound; 5) pit in front of the mound in the case of rotational treefalls; 6) part of the trunk close to the roots (deadwood). Vegetation on 45 plots of $1 \times 1 \mathrm{~m}$ in size and located close to but not affected by tree uprooting (reference plots, or reference communities) was also described. The results of the indirect ordination analysis revealed that the ecological and phytocoenotic differences between the plant associations of Querco - Tilietum cordatae and Aceri campestris - Tilietum cordatae persisted in the areas of catastrophic windthrow both on the plots of reference communities and in vegetation overgrowing pits and mounds. Ordination showed differences between the vegetation in the microsites formed by tree uprooting in a series of mound - deadwood - pit - reference community. On 251 plots, 78 vascular plant species were totally registered, among them 26 species were not found in the reference plots but occurred in the pit-and-mound microsites; 6 species were not found before the windthrow study in the descriptions of broadleaved and aspen forests of the Reserve, and 8 species were found in the descriptions of those forests no more than three times. New species are mostly species from the boreal (Phegopteris connectilis, Sambucus racemosa), nitrophilous (Rubus 
caesius), water-marsh (Epilobium hirsutum, Epilobium palustre), meadow-edge (Bromopsis inermis, Hypericum hirsutum, Conyza canadensis, Vicia cracca), and piny (Calamagrostis epigeios) ecological-coenotic groups. In general, the increase in plant diversity in the area of catastrophic windthrow is caused by the massive emergence of new microsites (pits, mounds and deadwood) and the subsequent appearance of species with different ecological and coenotic traits.

Keywords: windthrow, Kaluzhskie Zaseki Reserve, pit-and-mound topography, plant species diversity, DCA, ecological-coenotic groups.

For citation: Khanina L.G., Bobrovsky M.V., Zhmaylov I.V. Vegetation diversity on the microsites caused by tree uprooting during a catastrophic windthrow in temperate broadleaved forests. Russian Journal of Ecosystem Ecology. 2019;4(3). Available from: https://doi.org/10.21685/2500-0578-2019-3-1

Аннотация. Проанализировано разнообразие видов сосудистых растений, произрастающих на элементах ветровально-почвенных комплексов (ВПК) и образованных при падении деревьев в результате катастрофического ветровала 2006 г. в широколиственных лесах на территории заповедника «Калужские засеки». Получены размерные характеристики элементов ВПК для 110 вывалов 9 видов деревьев. Описана растительность 45 вывалов 8 видов деревьев на следующих элементах ВПК: вершина бугра, задняя и передняя стенки бугра, западина, передний клин (для провернутых вывалов) и прикомлевая часть ствола упавших деревьев (валеж). Растительность описана также на 45 площадках 1×1 м, расположенных рядом с ВПК, но не нарушенных ветровалом (фон или фоновые сообщества). Результаты непрямого ординационного анализа выявили, что экологические и ценотические различия между ассоциациями Querco-Tilietum cordatae и Aceri campestris-Tilietum cordatae сохраняются на участках массового ветровала как во фрагментах фоновых сообществ, так и в растительности на зарастающих вывалах деревьев. Одинация выявила различия растительности на микросайтах, формирующихся при вывале деревьев, в ряду бугор - валеж - западина фон. Всего на 251 площадке зарегистрировано 78 видов сосудистых растений, из которых 26 видов не встречались вне микросайтов вывалов, а присутствовали только на элементах ВПК; 6 видов не были встречены до исследования ветровала в описаниях широколиственных лесов и осинников заповедника и 8 видов были встречены там не более трех раз. В основном виды, присутствующие только на элементах ВПК, относятся к бореальной (Phegopteris connectilis, Sambucus racemosa), нитрофильной (Rubus caesius), водноболотной (Epilobium hirsutum, Epilobium palustre), лугово-опушечной (Bromopsis inermis, Hypericum hirsutum, Conyza canadensis, Vicia cracca) и боровой (Calamagrostis epigeios) эколого-ценотическим группам. В целом увеличение разнообразия растений при катастрофическом ветровале связано с массовым появлением новых микросайтов (элементов ВПК) и с увеличением участия на них видов разной экологической и ценотической приуроченности.

Ключевые слова: ветровал, заповедник «Калужские засеки», ветровально-почвенный комплекс, видовое разнообразие растительности, DCA, эколого-ценотические группы.

\section{Introduction}

Along with fires and mass outbreaks of insect pests, catastrophic windthrows are one of the major disturbances of forest ecosystems, and require study, analysis and assessment of their causes and consequences. Studying these disturbances is particularly relevant today, in the context of global changes of climate and natural resource management; such studies could be useful for forecasting the state of ecosystems and promoting sustainable ecosystem management [1-4]. There are a lot of papers on the mechanisms of windthrows [5-8], the influence of catastrophic windthrows, pitand-mound topography and deadwood on soil properties, biogeochemical cycles in ecosystems and carbon sequestration [9-21].

Traditionally, when studying windthrows, much attention is paid to their impact on forest vegetation changes. Assessing the influence of single and massive windthrows on the renewal of woody species is one of the focuses of the research [22-27]. The majority of studies are performed in boreal [28-30] and, less frequently, mixed hemiboreal $[25,26]$ forests. The studies performed in nemoral forests mainly focus on the changes in mono- and oligodominant forests with beech (Fagus sylvatica) predominance [31, 32], and most often these are mountain forests. Studies of the effect of windthrows and gap mosaic on the ground layer of vegetation are quite uncommon [33-40]; they rarely consider the microsite structure associated with the pit-and-mound topography [34, 36, 37, 40]; although studies on different species overgrowing deadwood are more frequent [41-43].

The aim of our research was to study the processes of overgrowing and to assess the diversity of vascular plants in pits and mounds formed after treefalls with uprooting in the areas of catastrophic windthrows in broadleaved forests. The research was carried out in the Kaluzhskie 
Zaseki Reserve, which is located in the subzone of broadleaved forests and which suffered from a massive windthrow in 2006.

\section{Materials and methods}

The study area. The Kaluzhskie Zaseki State Nature Reserve is located in the eastern European part of the broadleaved forest zone [44] in the south-east of the Kaluga Oblast where it borders with the Orel Oblast and the Tula Oblast; the geographical coordinates of the Reserve range from 53.5 to $53.9^{\circ} \mathrm{N}$ and from 35.6 to $35.9^{\circ} \mathrm{E}$ (Fig. 1). The Reserve was established in 1992 to protect the old-growth multi-species broadleaved forests growing on the site of the former Zaokskaya Abatis belt, which was the line of defence of the Muscovite state in the 16-18th centuries [45-47]. The stands of broadleaved forests are dominated by the common oak (Quercus robur), which is more than 300 years old in some patches. The maximum age of trees of other broadleaved species (common ash, Fraxinus excelsior; small-leaved lime, Tilia cordata; wych elm, Ulmus glabra; Norway maple, Acer platanoides, and field maple, A. campestre) varies from 150 to 170 years. Along with the broadleaved forests, there are forests dominated by aspen (Populus tremula), warty birch and downy birch (Betula pendula and B. pubescens), Scots pine (Pinus sylvestris), Norway spruce (Picea abies), and black alder (Alnus glutinosa); small areas are occupied by meadows [48].

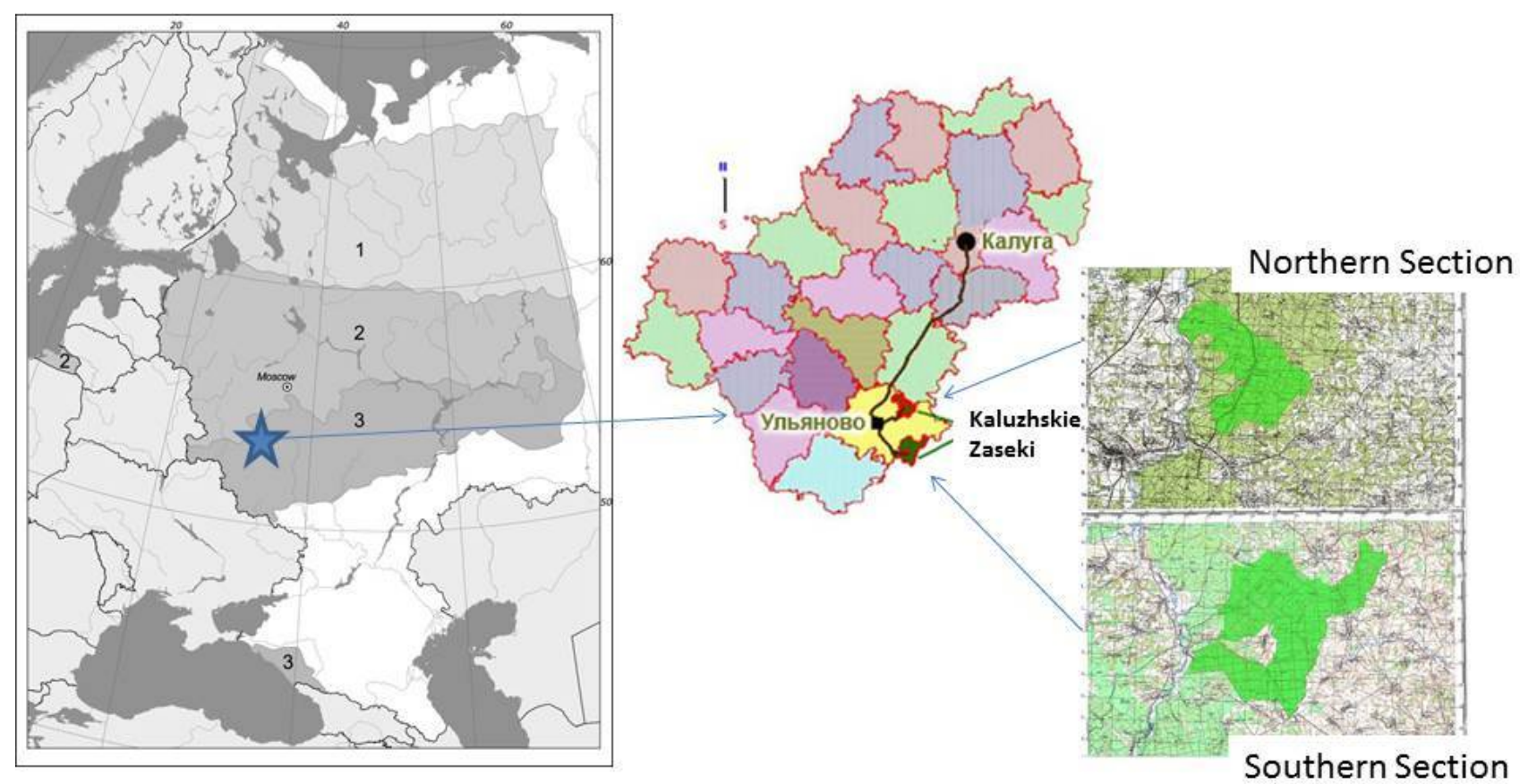

Fig. 1. Location of the Kaluzhskie Zaseki State Nature Reserve.

On the left side of the scheme you can see: 1 - boreal; 2 - hemiboreal; 3 - nemoral forest zones

The Reserve is located on the Russian platform, in the northwestern part of the Central Russian Upland, in the watershed of the Oka and Vytebet rivers (a tributary of the Zhizdra River). The prevailing elevation varies from 150 to $250 \mathrm{~m}$ above the sea level, the highest point is $275 \mathrm{~m}$ asl. The erosive hilly terrain is formed by a gently sloping cover of glacial moraine and is densely dissected by ravines, gullies and rivers. The average annual temperature is $4.4^{\circ} \mathrm{C}$. The average annual precipitation is $700 \mathrm{~mm}$ [49].

A massive windthrow occurred in the Southern section of the Reserve (mainly within the Yagodnenskoye Forest District) in August 2006 due to a hurricane wind accompanied by a heavy thunderstorm, sometimes with hail. According to satellite images and ground mapping the total area of the damaged forests is 285 ha: there are 291 damaged patches with the areas ranging from 0.04 to 51 ha (Figs. 2 and 3); middle-aged and mature aspen and birch forests were the most severely broken, while old-aged oak forests were the least affected [50]. During the windthrow, some of the trees fell with uprooting that formed pit-andmound topography (Fig. 4), and some of the trees were broken off. The analysis of the number of damaged trees on five sample plots established in 2010 showed that the number of broken trees and those fallen with uprooting was approximately the same; at that, the area occupied by lying tree trunks 
was vaster than the area occupied by pit-and-mound topography: the proportion of the former ranged from 17 to $32 \%$ and the latter from 6 to $25 \%$ of the plot area [50]. The average stock of deadwood varied from 198 to $463 \mathrm{~m}^{3} / \mathrm{ha}$.

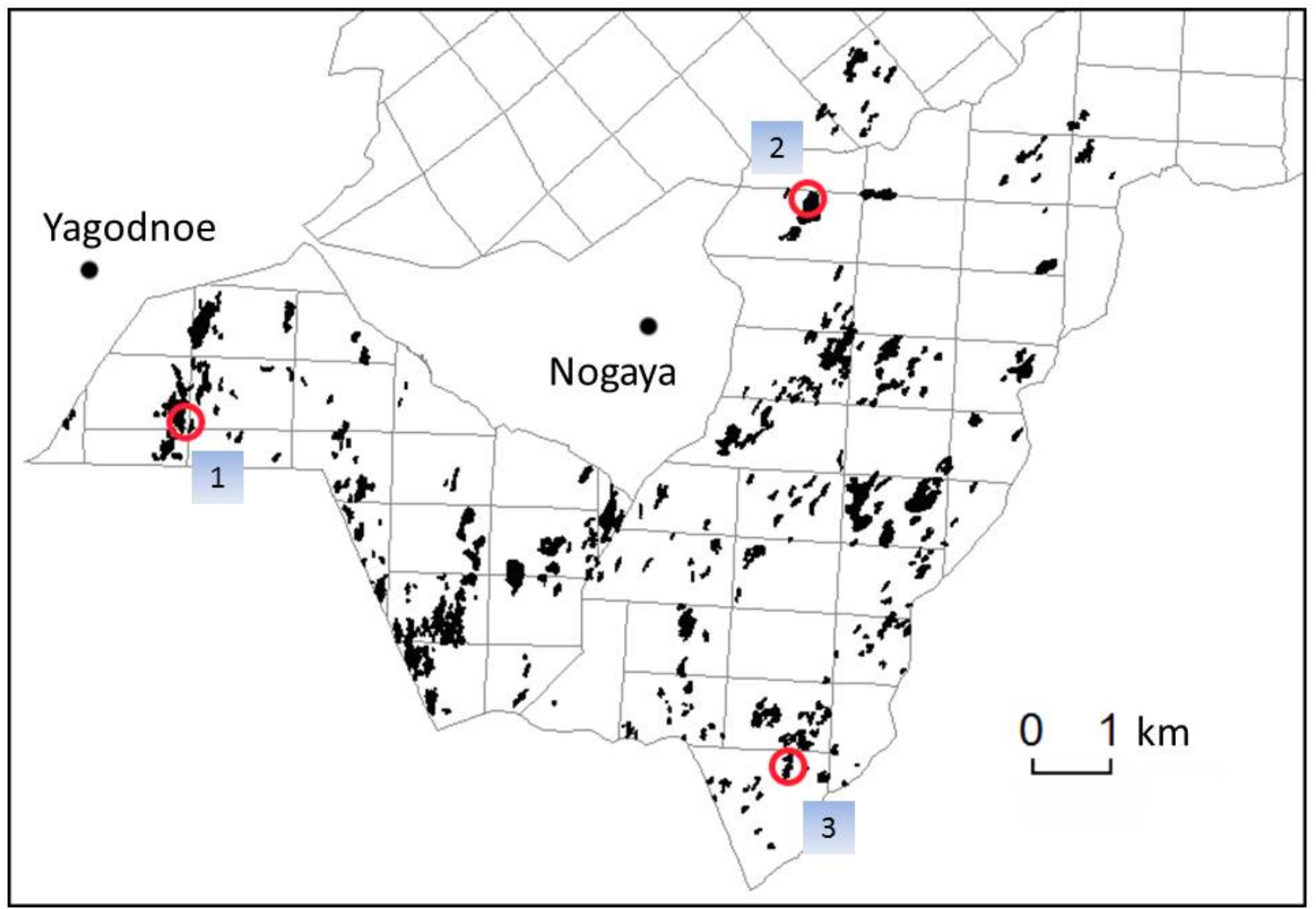

Fig. 2. Patches of the 2006 massive windthrow (the black icons) within the Southern section of the Kaluzhskie Zaseki Reserve. Circles 1-3 are the Areas where pit-and-mound topography was studied

The pit-and-mound topography was studied in three local areas (Fig. 2). Area 1 is located near Yagodnoye village; before the windthrow there was an aspen-broadleaved forest with the predominance of Populus tremula, Tilia cordata, Quercus robur with the presence of Picea abies (sample plots 1 and 3 in [50]). Soddy podbours and soddy-podzolic soils on the fluvioglacial sands dominate. Area 2 is located near Nogaya village; before the windthrow it was occupied by a broadleaved forest with the predominance of Fraxinus excelsior and Populus tremula with the presence of Tilia cordata, Acer platanoides, Quercus robur, Betula spp. (sample plots 4 and 5 in [50]). Soddy-podzolic and grey soils including gleyic soils on the loams prevail. Area 3 is located in the south-east of the Southern section of the Reserve; before the windthrow it was a broadleaved forest with Populus tremula and Betula spp. The prevailing soils are soddy podbours located on two-term deposits (thin fluvioglacial sands on morainic loams). Overall, the vegetation of Area 1 can be attributed to the Querco-Tilietum cordatae association, Laivinsh
1986 ex Laivinsh in Solomesč et al. 1993. Diagnostic species of this association belonging to the nemoral ecological-coenotic group (ECG) show high constancy, at the same time boreal species (Gymnocarpium dryopteris, Luzula pilosa, Maianthemum bifolium, Phegopteris connectilis, etc.) can also be found here. Vegetation of Area 2 can be attributed to the Aceri campestris Tilietum cordatae ass. nov. hoc loco [51], it shows high constancy of Acer campestre, Euonimus europaea, and Allium ursinum. Aceri campestris Tilietum association is usually found on wetter and richer soils [51]. The vegetation of Area 3 falls in between these two associations.

Sampling design. To assess the vegetation diversity of pits and mounds formed after treefalls with uprooting in the patches of the catastrophic windthrow, in 2010 (4 years after the windthrow) we investigated the vegetation of the following microsites (Fig. 5): 1) top of the mound; 2) back (relatively to the position of the trunk) side of the mound; 3) front side of the mound; 4) pit over the mound (i.e. pit in the usual sense of the term); 5 ) pit in front of the mound (only in the case of 


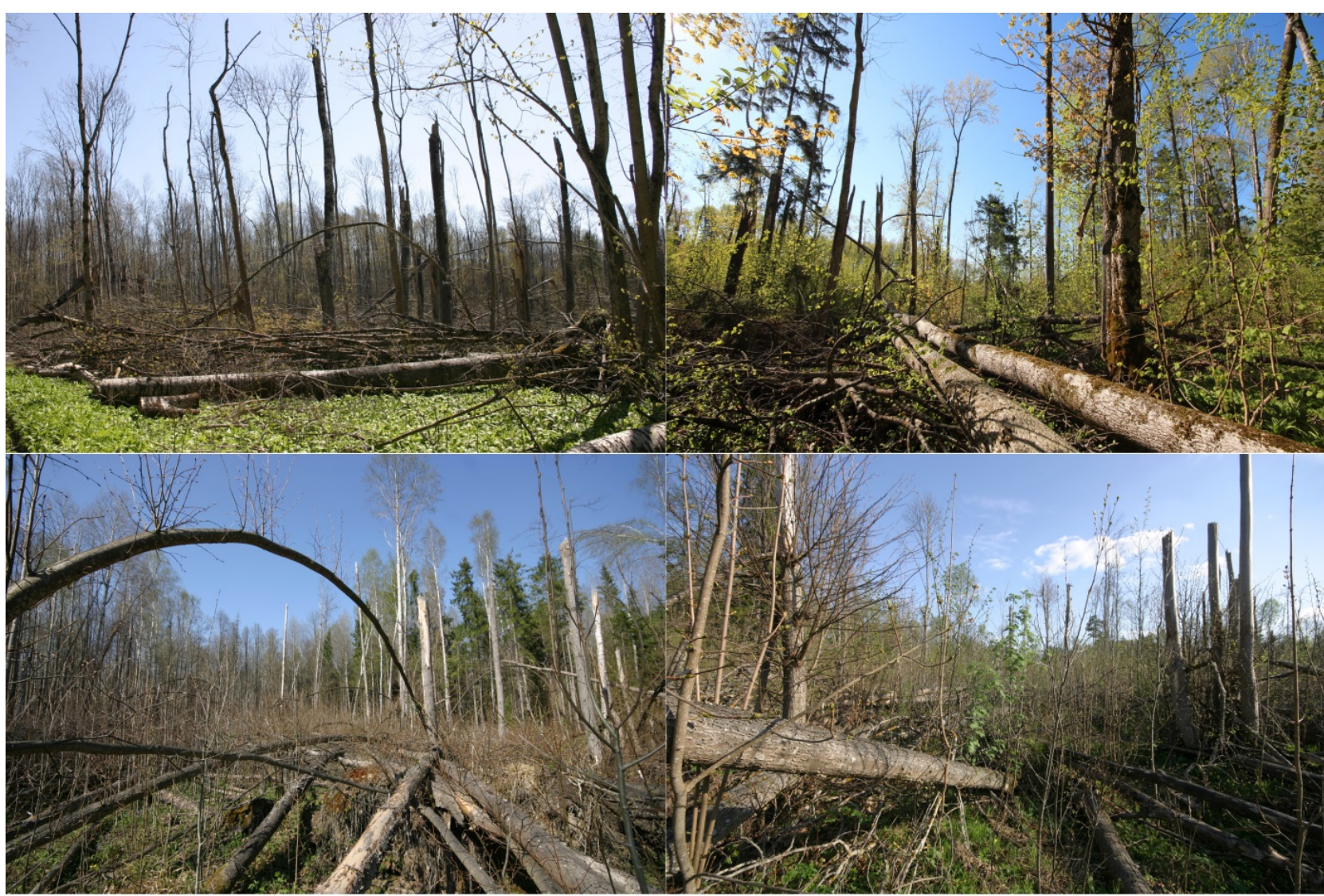

Fig. 3. Massive windthrow in the Kaluzhskie Zaseki Reserve. Photo by M. V. Bobrovsky

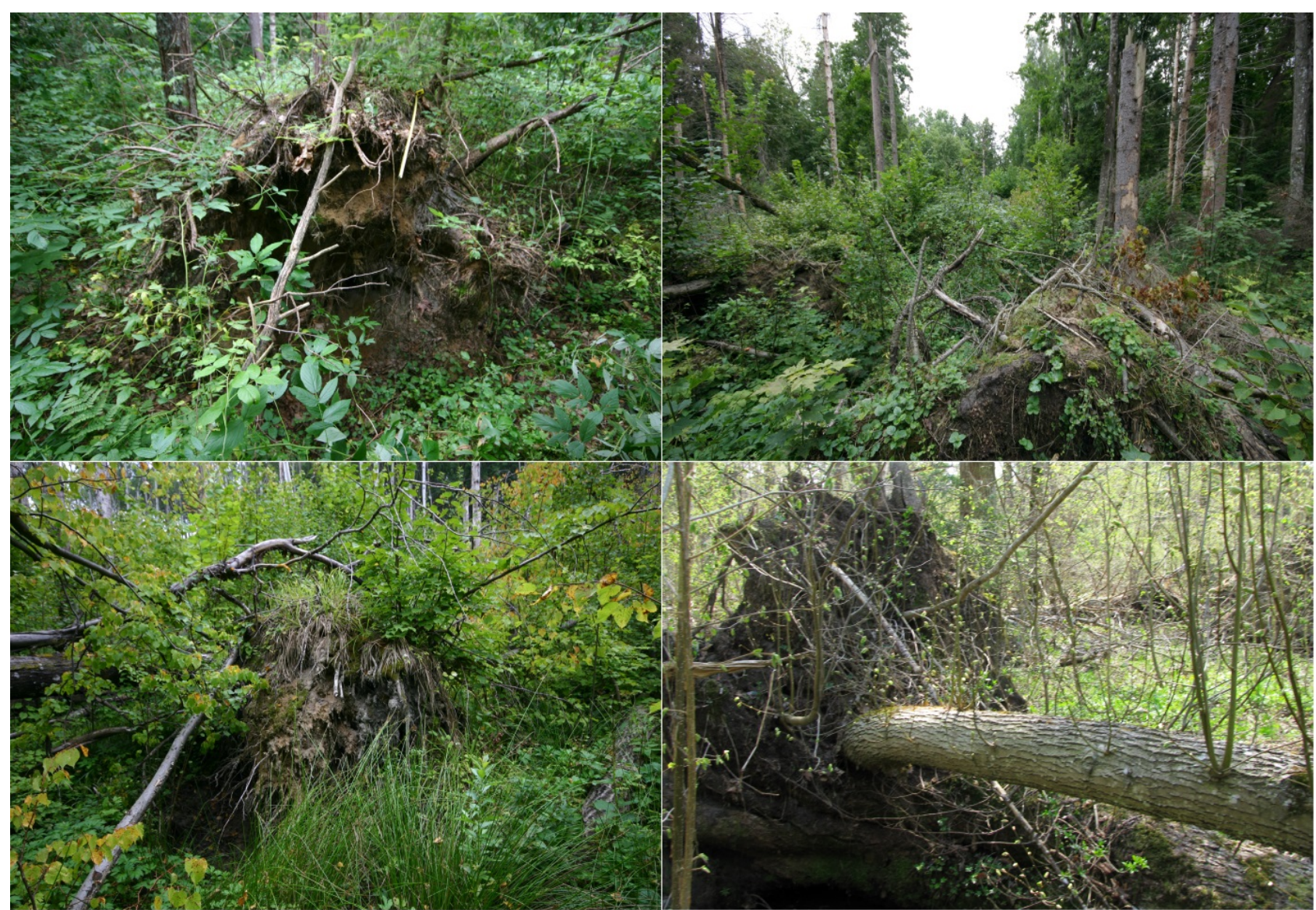

Fig. 4. Pit-and-mound microsites on the patches affected by the 2006 massive windthrow in the Kaluzhskie Zaseki Reserve. Photo by M. V. Bobrovsky 


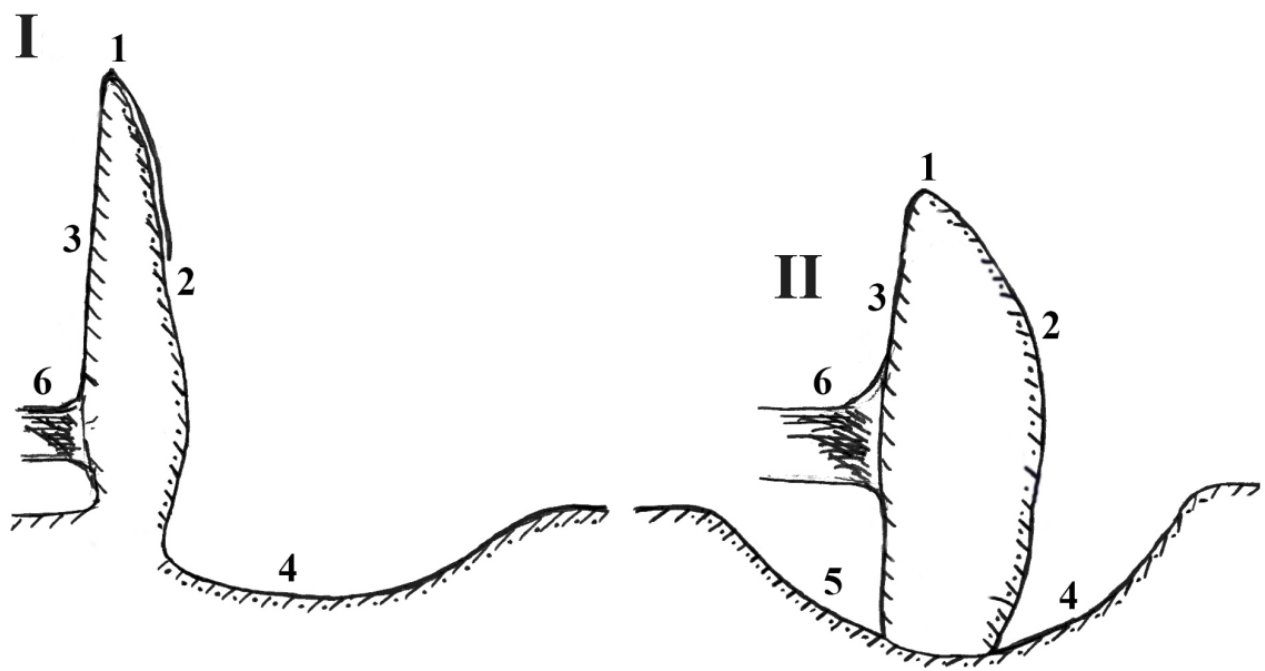

Fig. 5. Investigated pit-and-mound microsites for non-rotational (I) and rotational (II) treefalls: 1 - top of the mound; 2 - back side of the mound; 3 - front side of the mound; 4 - pit over the mound; 5 - pit in front of the mound; 6 - deadwood

rotational treefalls [19]); 6) deadwood, the part of the trunk close to the roots of a fallen tree (vegetation was listed on a plot of $1 \mathrm{~m}^{2}$ ).

We measured diameter at $1.3 \mathrm{~m}$ from the root collar (DBH) and size of the pits and mounds of 110 trees fallen with uprooting. For each microsite, mentioned above and formed by 45 fallen trees, vascular plant species were listed and their percentage cover was visually estimated for two vegetation layers: layer $C$ with the height of herbaceous plants and layer $B$ consisting of higher trees and shrubs. Next to each described fallen tree we also listed vascular plant species at a reference plot of $1 \times 1 \mathrm{~m}$, which was not affected by treefalls. Sometimes there was no vegetation on the deadwood, the back/front side of the mound or in the pit in front of the mound. The area occupied by bare soil, leave or woody litter and green mosses was also estimated (in percent) on each microsite. Totally, 251 vegetation plots were sampled: 206 pit-and-mound microsites and 45 reference plots.

Field data analysis. In order to analyze variations in the vegetation, indirect ordination analysis of vegetation plots was conducted on the numeric scores of species abundance using the Detrended Correspondence Analysis (DCA) method [53] performed by the PC-ORD 6.21 program [52]. The numeric scores of abundance were obtained from the percentage cover of the species according to the following rules: cover less than $1 \%-0.5$; cover 1 to $10 \%-1 ; 10$ to $25 \%-$ $2 ; 25$ to $50 \%-3 ; 50$ to $75 \%-4$, above $75 \%-5$. The ordination effectiveness was evaluated by the after-the-fact coefficient of determination between relative Euclidean distance in the unreduced species space and Euclidean distance in the ordination space [52]. To assess the significance of ordination axes, we performed a randomization test
(Monte-Carlo procedure). It should be noted that according to the PcOrd program authors [52], only the significance of the first axis of DCA may be assessed correctly enough.

To interpret the ordination axes, correlation vectors with the environmental characteristics of the plots and with the number of species of different ecological-coenotic groups were built. Landolt's indicator species values [54] weighted by species abundance and averaged for plots were used as their environmental characteristics. The EcoScale program [55] was used to calculate these weighted averages. Ecological-coenotic groups (ECGs) were understood as described by $\mathrm{O}$. V. Smirnova and L. B. Zaugolnova [56, 57] and further specified by V. E. Smirnov et al. [58, 59]. The following six ECGs were used in this work: boreal $(\mathrm{Br})$, nemoral $(\mathrm{Nm})$, nitrophilous $(\mathrm{Nt})$, piny $(\mathrm{Pn})$, meadow-edge $(\mathrm{Md})$, and water-marsh (Wt). The ecological characteristics of the plots and the number of species of different ECGs were also used to assess the environmental conditions and structural diversity of vegetation on the microsites, respectively.

Dominant, constant and indicator species were identified to characterize the vegetation of the microsites and reference plots. The indicator species were determined by the IndVal method [60], which takes into account the occurrence and average abundance of species in the plots of each group, as well as the average abundance of species in all groups of plots. The statistical significance of the obtained indicator values $(I V)$ was checked by the Monte-Carlo procedure; the species with the probability of incorrect rejection of the null hypothesis $(p)$ not more than 0.05 were seen as indicators for a microsite. 
Alpha-, beta-, and gamma-diversity [61] of vascular plants in the microsites were also calculated. Compositional diversity was calculated as the average number of species per plot (species density) and the total number of species in all plots of the corresponding microsite or in the reference community (species richness). The differential diversity was estimated using the Whittaker index and calculated according to the formula $\beta_{w}=\frac{\gamma}{\bar{\alpha}}-1$, where $\gamma$ stands for species richness; $\bar{\alpha}-$ for species density.

To analyze the contribution of microsites to the total plant diversity of the broadleaved forests of the Reserve we compared the list of species of the microsites with the species list of reference plots and the species lists of broadleaved, nemoral aspen and nemoral birch forests taken from the general database of the geobotanical relevés of the Reserve [62].

\section{Results and discussion}

Dimensions of pit-and-mound microsites. Mounds and pits of 9 tree species were measured (Table 1). As in the earlier study performed by M. V. Bobrovsky [63] on the same windthrow sites in 2007 and 2009, it turned out that the Picea abies treefalls are the largest in size. Among deciduous trees, in our research, Ulmus glabra, Betula spp., and Quercus robur on average formed the highest mounds when fell with uprooting; Acer platanoides, Ulmus glabra, and Betula spp. formed the longest pits. It should be noted that in general the dimensions of mounds and pits differed from the values obtained earlier for the same microsites: immediately after the windthrow the mounds were higher and the pits longer; this decrease in the size is an obvious process occurring over time due to the crumbling of the soil clods. On average, bare soil occupied the largest areas on the mounds (Fig. 6); leaf litter prevailed in the pits and in the reference plots; proportion of green mosses was highest on the deadwood and on tops of the mounds.

Vegetation description. The highest number of vegetation plots was sampled at Fraxinus excelsior treefalls (vegetation on ten fallen trees was described), followed in descending order by the treefalls of Populus tremula (8), Tilia cordata and Ulmus glabra (7 each), Betula spp. and Quercus robur (4 each), Acer platanoides (3), and Picea abies (2). The results of indirect ordination analysis of vegetation plots revealed no significant difference between the vegetation growing on the microsites formed by trees of different species. However, the results showed the presence of two main gradients along which the vegetation varies (Fig. 7). The cumulative coefficient of determination for the first three axes is rather high $(52.4 \%)$; the first and second axes are significant $\left(p_{1}=0.054, p_{2}=0.015\right)$, that generally indicates a rather high quality of the ordination [52].

Size of the microsites of 110 fallen trees of different species measured in 2010 at the windthrow of 2006 (the Southern section of the Kaluzhskie Zaseki Reserve), $\mathrm{cm}$

\begin{tabular}{|c|c|c|c|c|c|c|c|c|c|c|c|}
\hline & \multicolumn{2}{|c|}{ Mound height } & \multicolumn{2}{|c|}{ Mound width } & \multicolumn{2}{|c|}{ Mound thick } & \multicolumn{2}{|c|}{ Pit length } & \multicolumn{2}{|c|}{ DBH $^{*}$} & $n^{* *}$ \\
\hline & $\begin{array}{l}\text { Mean } \\
\text { value }\end{array}$ & Error & $\begin{array}{l}\text { Mean } \\
\text { value }\end{array}$ & Error & $\begin{array}{l}\text { Mean } \\
\text { value }\end{array}$ & Error & $\begin{array}{l}\text { Mean } \\
\text { value }\end{array}$ & Error & $\begin{array}{l}\text { Mean } \\
\text { value }\end{array}$ & Error & \\
\hline Acer campestre & 35.0 & 5.0 & 70.0 & 20.0 & 25.0 & 5.0 & 40.0 & 0.0 & 10.5 & 3.5 & $2 / 2$ \\
\hline Acer $p$ & 105.0 & 6.5 & 267.5 & 13.1 & 62.5 & 2.5 & 137.5 & 8.5 & 25.0 & 2.9 & $5 / 4$ \\
\hline Betula $\mathrm{s}$ & 121.1 & 12.7 & 258.9 & 23.6 & 67.2 & 7.4 & 131.1 & 18.1 & 29.3 & 1.8 & $12 / 9$ \\
\hline $\begin{array}{l}\text { Fraxinus } \\
\text { excelsior }\end{array}$ & 95.3 & 9.2 & 2 & 18.8 & 63.4 & 4 & .3 & 12.3 & 24.3 & 1.1 & $19 / 19$ \\
\hline Picea abies & 40.0 & 28.3 & 615.0 & 49.5 & 65.0 & 35.4 & 235.0 & 63.6 & 43.3 & 12.1 & $3 / 2$ \\
\hline Popul & 102.2 & 7.9 & 215.0 & 11.4 & 75.0 & 4.7 & 87.8 & 9.7 & 32.4 & 1.2 & $20 / 18$ \\
\hline Quercus robur & 120.0 & 17.6 & 274.0 & 41.2 & 72.0 & 4.9 & 118.0 & 15.0 & 40.9 & 6.2 & $7 / 5$ \\
\hline Tilia cordata & 78.9 & 6.3 & 196.7 & 11.1 & 62.8 & 3.2 & 72.3 & 8.4 & 21.7 & 1.1 & $33 / 32$ \\
\hline Ulmus glabra & 132.5 & 14.6 & 330.0 & 33.2 & 58.8 & 3.5 & 135.0 & 7.1 & 30.7 & 2.2 & $9 / 8$ \\
\hline
\end{tabular}

Note: * diameter at $1.3 \mathrm{~m}$ height; ** sample size for $\mathrm{DBH} /$ other variables.

Variation of the vegetation along the first axis is defined by ecotopic and floral factors: Areas 1 and 2 are distinguished quite well along this axis, whereas Area 3 lies in between (Fig. 7a). Thus, the vegetation on the soddy podbours / soddy-podzolic soils on fluvioglacial sands (Querco - Tilietum cordatae ass.) and the vegetation on soddy- podzolic and grey soils on the loams (Aceri campestris - Tilietum cordatae ass.) is differentiated well along the first axis; the vegetation on the soddy podbours on two-term deposits lies between these associations in the ordination diagram. 


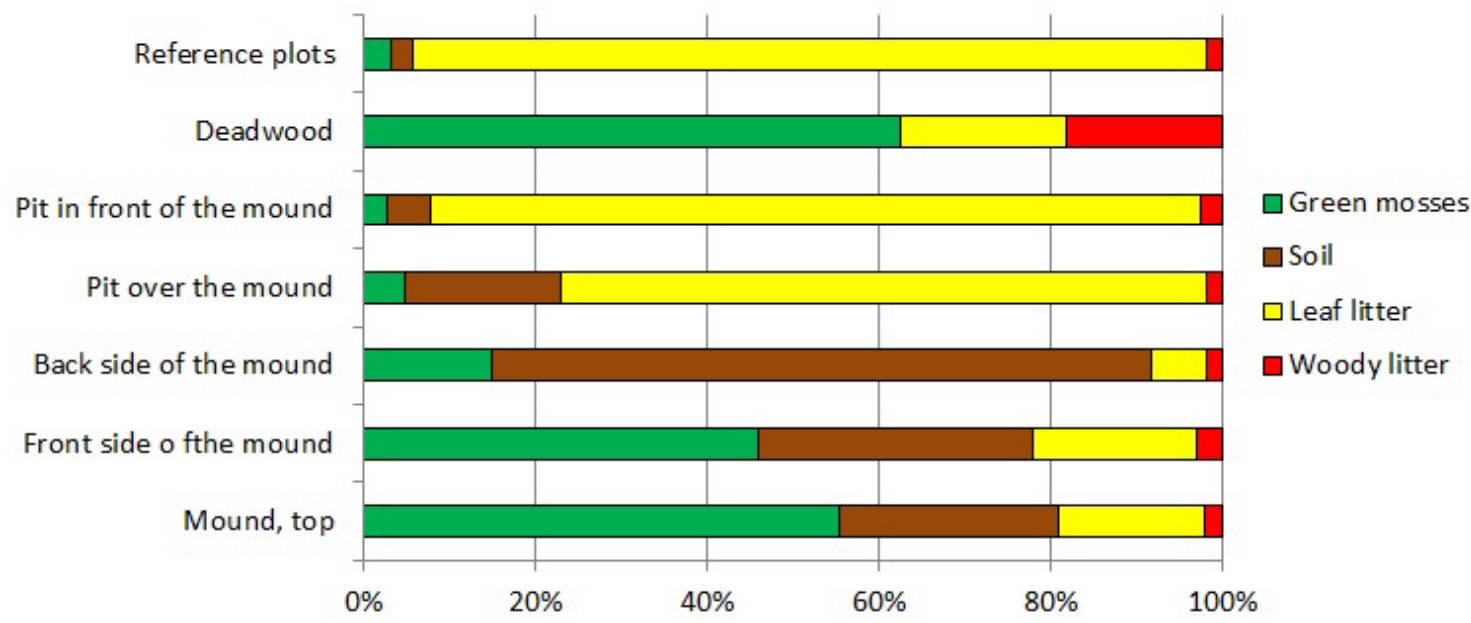

Fig. 6. The mean proportion of areas of various substrates and green mosses on the pit-and-mound microsites and the reference plots in the studied windthrow areas

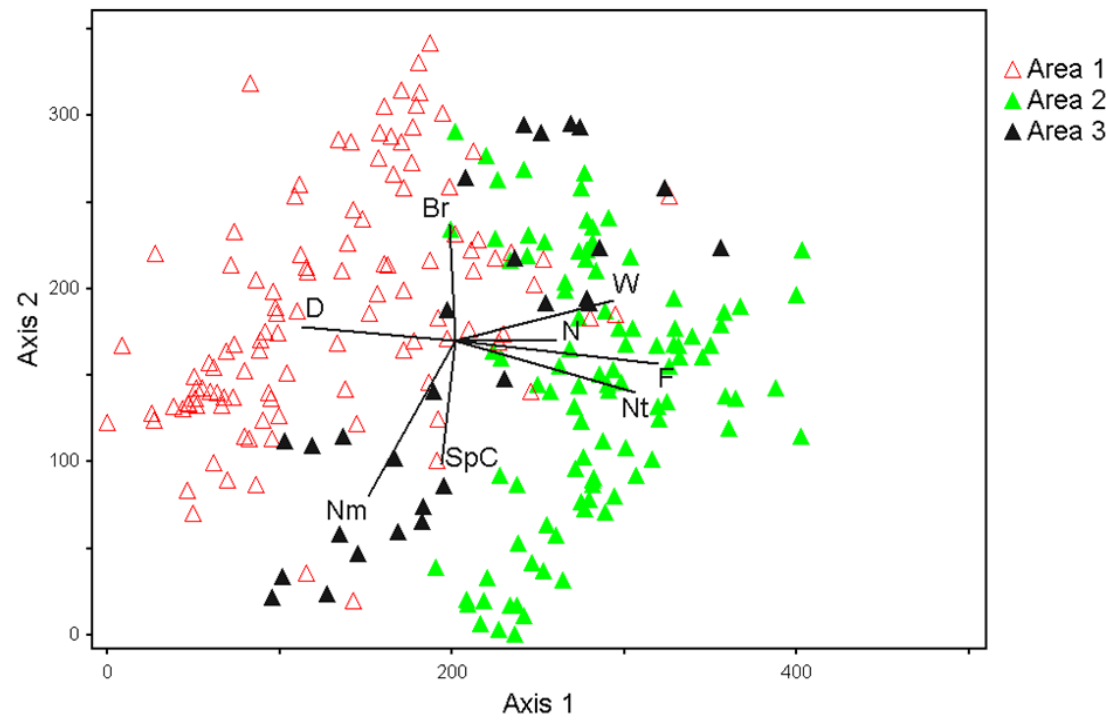

a)

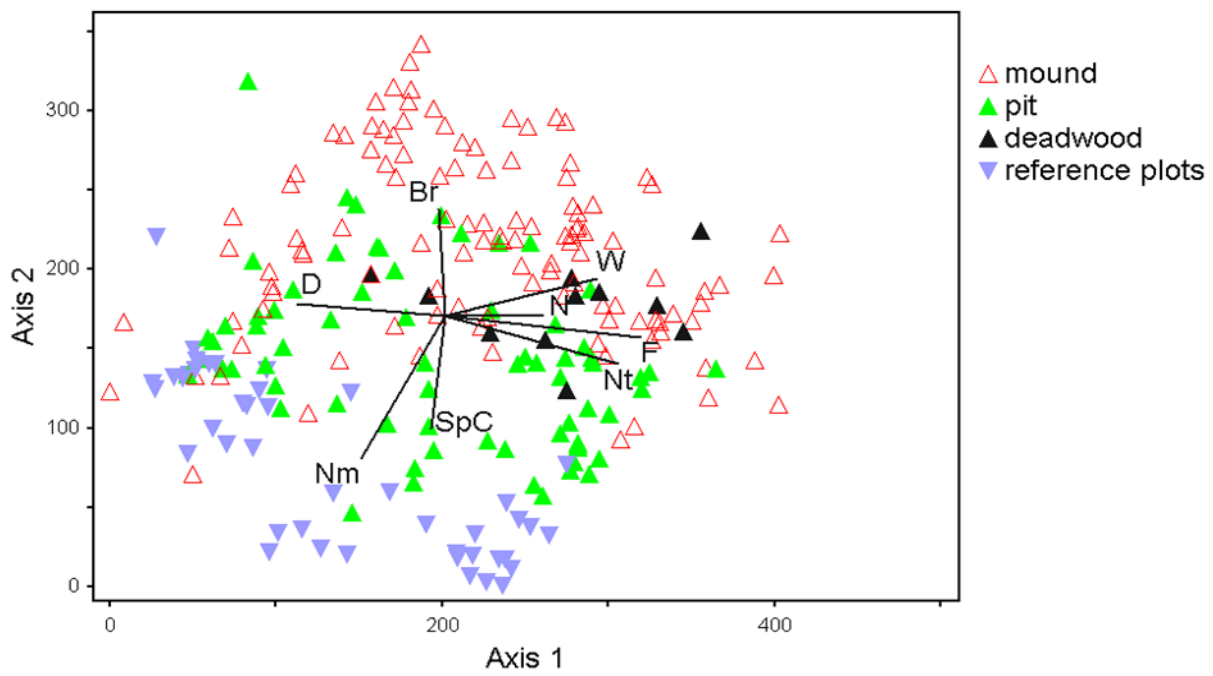

b)

Fig. 7. Ordination of vegetation plots by DCA: $a$ - studied Areas $1-3$ in accordance with Fig. 2 ; $b$ - microsites: the "mound" consists of the top of the mound and the front/back sides of the mound; "the pit" includes the pits over and in front of the mound; "deadwood" and "reference plot" - see the text. Vectors: $\mathrm{SpC}$ - the number of species in the layer $\mathrm{C} ; \mathrm{Br}, \mathrm{Nt}, \mathrm{Nm}$ - the number of species of the boreal, nitrophilous, and nemoral ecological-coenotic groups; W, N, F, D - ecological characteristics of plots calculated by the Landolt's tables: soil moisture variability, fertility, moisture, and aeration 
Among the analyzed environmental characteristics, soil moisture F, variability of moisture $\mathrm{W}$, and soil fertility $\mathrm{N}$ correlate most with the first axis: $r=0.69,0.61$, and 0.48 , respectively. Their vectors are directed towards the wetter and richer in soil biotopes of Aceri campestris Tilietum cordatae ass. located on the loams and with a large number of nitrophilous species $(\mathrm{Nt}$, $r=0.65)$. The aeration vector $\mathrm{D}$ associated with the granulometric composition of the soil (the higher the value is, the larger fractions there are in the soil) is directed towards Area 1, located on fluvioglacial sands $(r=-0.60)$.

On the second axis of the ordination diagram (Fig. $7 b$ ), the vegetation varies along the microsites on the plots of massive windthrows: from the vegetation on the mounds (consisting of the top of the mound and the front/back sides of the mound) through the vegetation of the pits (pits over and in front of the mound) to the vegetation of the reference plots; the vegetation on the trunks of the fallen trees occupies an intermediate position in the diagram between the vegetation of the mound and that of the pit. Among the analyzed characteristics, the number of boreal and nemoral species $(r=0.52$ and -0.60 , respectively) shows the largest correlations with the second axis which means that there is a relatively larger number of boreal species in microsites of the mound and a relatively larger number of nemoral species in the reference plot and in the pits. Both the vectors of the species number in the layer $C$ and of the nemoral species are directed towards the pits and the reference plots $(\mathrm{SpC}, r=-0.53)$, where the most species of vascular plants occurred (Fig. 8; Table 2). No strong correlations between the ecological characteristics of the plots and the second axis are observed, that means that there are no important differences between the ecological characteristics of the studied microsites according to the Landolt's tables [54].

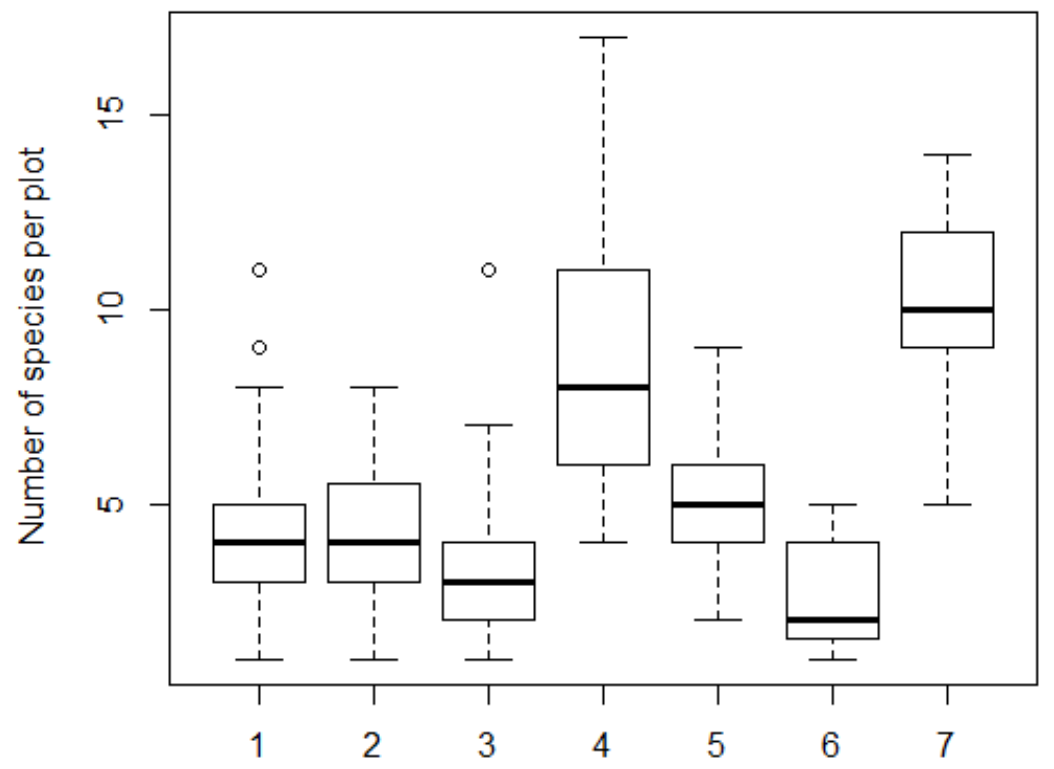

Microsites

Fig. 8. Box plots of the number of vascular plant species per plot occurred in the microsites: 1 mound, 2 front and 3 back sides of the mound, 4 pit over the mound, 5 pit in front of the mound, 6 deadwood, 7 reference plot of $1 \times 1 \mathrm{~m}$. The midline is the median, the box sides represent the first and third quartiles; the length of the vertical segments is determined by the distance from the box side to the smallest/largest value that falls within one-and-a-half interquartile range from the lower/upper side of the box; single points are outliers

In general, indirect ordination revealed differences in the vegetation of three investigated areas (along the first axis) as well as differences between microsites and the reference communities (along the second ordination axis). The analysis of dominant, constant and indicator species of the investigated microsites and reference plots made it possible to specify the observed difference.

Dominant species, or the species covering over $50 \%$ of an analyzed area, differed for the microsites and reference plots. Mounds and pits were dominated by tall herbaceous species growing on rich soils, i.e. Rubus idaeus, Urtica dioica, Impatiens noli-tangere; undergrowth of Padus avium also occurred there with high coverage. Besides, Tilia cordata individuals of seed origin covered from 30 to $60 \%$ of some pits, whereas it was never seen in the forest not affected by windthrow (only lime individuals of vegetative origin occurred there). Reference plots (over $75 \%$ 
of the coverage) were dominated by the typical nemoral species Aegopodium podagraria, Carex pilosa, and Mercurialis perennis; the nitrophilous species Urtica dioica with high cover (50 and $80 \%$ ) was found in two plots. The deadwood was dominated (with $40 \%$ of the coverage) by the nemoral herbs Galeobdolon luteum and Glechoma hirsuta.

Table 2

Species diversity of vascular plants on the pit-and-mound microsites and in the reference plots in the 2006 windthrow in the Kaluzhskie Zaseki Reserve

\begin{tabular}{|l|c|c|c|c|c|}
\hline & $\begin{array}{c}\text { Mean number } \\
\text { of species }\end{array}$ & $\begin{array}{c}\text { Standard error } \\
\text { of the mean }\end{array}$ & $\begin{array}{c}\text { Total number } \\
\text { of species }\end{array}$ & Whittaker index & $\begin{array}{c}\text { Number } \\
\text { of the plots }\end{array}$ \\
\hline Mound, top & 4.6 & 0.31 & 43 & 8.3 & 45 \\
\hline Front side of the mound & 4.2 & 0.29 & 38 & 8.0 & 44 \\
\hline Back side of the mound & 3.5 & 0.33 & 28 & 7.0 & 37 \\
\hline Pit over the mound & 8.6 & 0.49 & $\mathbf{5 9}$ & 5.9 & 45 \\
\hline Pit in front of the mound & 5.1 & 0.36 & 26 & 4.1 & 23 \\
\hline Deadwood & 2.7 & 0.43 & 10 & 2.8 & 12 \\
\hline Reference plots & $\mathbf{1 0 . 0}$ & 0.32 & 52 & 4.2 & 45 \\
\hline
\end{tabular}

Constant species of microsites, as well as dominant ones, mostly overlapped but they differed from constant species of reference plots, although two nemoral species, Glechoma hirsuta and Galeobdolon luteum, were found in more than $50 \%$ of plots on almost every microsite and in reference plots as well. On the treefall mounds, their tops, front and back sides and in pits, Rubus idaeus occurred in $50 \%$ of cases (Fig. $9 a$ ). The nitrophilous herb Impatiens noli-tangere occurred on the mounds rarer than Rubus idaeus but it was found in $75 \%$ and $50 \%$ of the pits located in front of the mounds and on deadwood, respectively (Fig. 9b). Aegopodium podagrarium and Urtica dioica occurred on $58 \%$ of the pits located in front of the mounds. The typical nemoral species Pulmonaria obscura, Asarum europaeum and Mercurialis perennis occurred on over $50 \%$ of the reference plots.

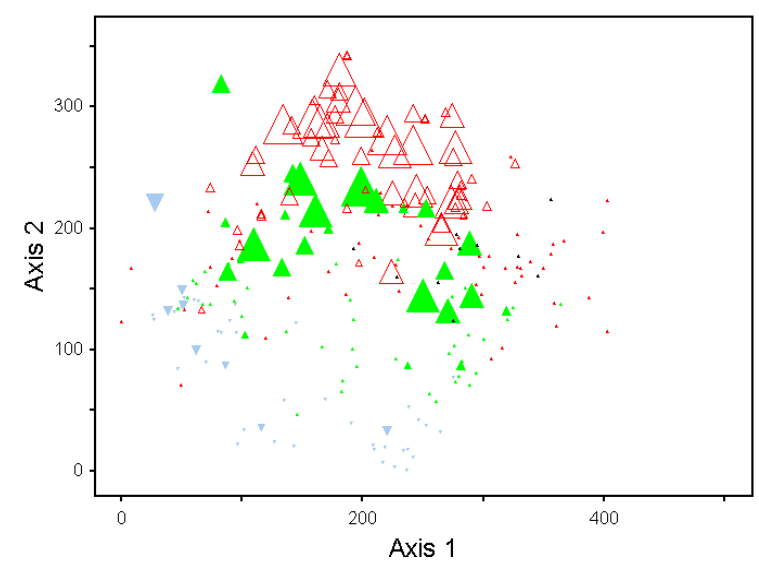

a)

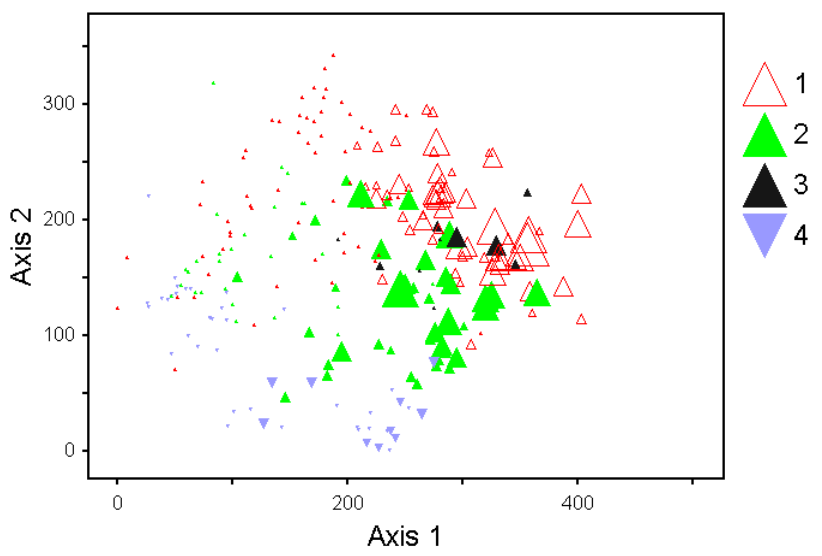

b)

Fig. 9. The position of Rubus idaeus ( $a$ ) and Impatiens noli-tangere (b) in the ordination diagram. Microsites: 1 - mound; 2 - pit; 3 -deadwood; 4 - reference plots

The composition and abundance of plant species on different microsites overlapped to a large extent, therefore there were only a few indicator species of microsites, and they had relatively low indicator values. For the mounds it was nemoral sedge Carex digitata; for pits Tilia cordata, and for pits in front of the mounds Impatiens noli-tangere. In the reference communities, the highest indicator values were shown by Pulmonaria obscura and Aegopodium podagrarium. When joining the elements of pit-andmound topography into larger units, as mound (together with the mound top, front, and back sides), pit (with the pits over and in front of the mound) and deadwood, Rubus idaeus was found to be the indicator species for the mound $(I V=27.6 \%)$, and Urtica dioica for the pit (22.9 \%), whereas Pulmonaria obscura and Aegopodium podagrarium remained the most vivid indicators of the reference communities ( $I V=60.3$ and $60.0 \%$, respectively). 
Thus, although the pit-and-mound microsites differed slightly from the reference plots in ecological characteristics, they showed a relative increase in the number and abundance of tall herbaceous species of the boreal and nitrophilous ecological-coenotic groups demanding rich soil. It can be assumed that this is due to an increase in available nitrogen in the pit-and-mound microsites and an increase in the illumination in general in the areas of massive windthrow due to simultaneous fall of many tree individuals.

Vegetation diversity assessment. A total of 78 species of vascular plants were listed at 251 vegetation plots: 12 tree, 4 shrub, and 62 herbaceous species. At that, 26 species occurred only in the pit-and-mound microsites and were not found in the reference plots; these species are as following: 3 tree species (Salix caprea, Pinus sylvestris, and Betula pendula), 2 shrub species (Euonymus verrucosa and Sambucus racemosa), and 20 herbaceous species. Six vascular plant species were not listed before the windthrow study in the relevés of broadleaved, nemoral aspen, and nemoral birch forests of the Reserve. Those are the meadow species Erigeron (Coniza) canadensis and Hypericum hirsutum which are rarely found in the Reserve in general; Trifolium pratense which is common for the meadows; nitrophilous semishrub Rubus caesius, which rarely occurred in the Reserve; and two water-marsh species: the fairly common Epilobium palustre and the rare species E. hirsutum, which was firstly found in 2010 on the windthrow and in the floodplain of the Moshok River (as N. M. Reshetnikova observes, Epilobium hirsutum has been spreading quite successfully throughout the Reserve since 2014). Eight plant species found on the pit-and-mound microsites have been listed in geobotanical relevés of broadleaved and aspen forests of the Reserve less than three times [62], i.e. the boreal shrub Sambucus racemosa, the boreal fern Phegopteris connectilis, the meadow-edge species Impatiens parviflora, Bromopsis inermis, Leontodon autumnalis, Vicia cracca and Cirsium arvense, as well as the piny grass Calamagrostis epigeios and the nemoral herb Chelidonium majus. Thirteen species of plants were found only in one microsite. Tree individuals of seed origin for many tree species, such as Tilia cordata, Ulmus glabra, Fraxinus excelsior, Acer platanoides, Padus avium, Salix caprea, Betula spp., and Populus tremula, were often found on the pit-and-mound microsites. Highest compositional diversity was observed in pits located over the mounds and in reference plots (see Fig. 8, 9; Table 2). The mean number of species per plot was higher in reference plots, whereas the total species richness was higher in pits. The compositional diversity of vegetation on other microsites decreased as follows: top of the mound - front side - back side - pit in front of the mound - deadwood. Beta diversity was highest on the mound microsites; it was lower in the pits and reference plots. The structural diversity of vegetation was also higher on the mounds and in the pits due to the boreal, nitrophilous, watermarsh and meadow-edge species (Fig. 10). The contribution of species of these groups into diversity is more evident in the ecological-coenotic spectra of the total species lists than in the spectra of their mean number. In general, ecologicalcoenotic structure of vegetation in the reference plots was similar to the structure of broadleaved and aspen forests in the Reserve [48] where the proportion of nemoral species is $80-90 \%$. In the pit-and-mound microsites, proportion of nemoral species is lower (from 50 to $71 \%$ ); the number and proportion of boreal species are highest in all mound microsites and in the pits located over the mounds.

When assessing the total plant species diversity, it should also be noted that high cover of green mosses was observed on the mounds and on the deadwood (see Fig. 6). On average, mosses occupied $15 \%$ of the mound back side area, $46 \%$ of the mound front side area and $55 \%$ of the tops of the mounds. The mean cover of green mosses in the lying trunks close to the roots was $62 \%$, whereas the cover of green mosses in reference plots was $1-2 \%$. This means that the windthrow significantly increased the participation of mosses in the ground layer of the studied broadleaved forest communities.

Thus, the analysis of vegetation listed 4 years after the windthrow on 45 treefalls and on 45 reference plots of $1 \times 1 \mathrm{~m}$ showed the increased diversity of vascular plants due to the emergence of new microsites. Our observations showed, as compared to single treefalls in the broadleaved forest, a massive windthrow causes the greater percentage of trees to fall with uprooting creating large pits and mounds. As a result, new microsites are forming and species with various ecological-coenotic traits can settle and grow there. 

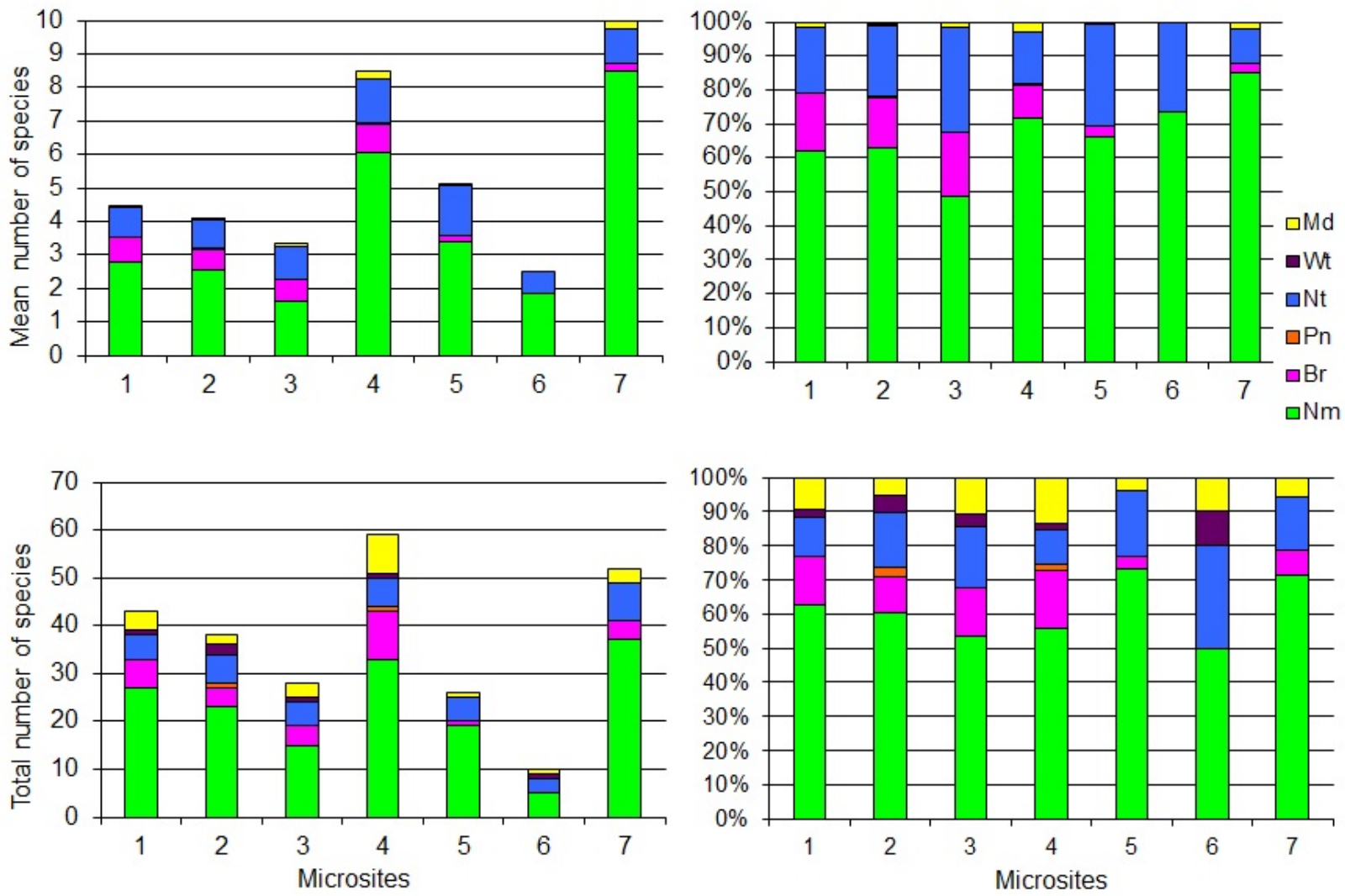

Fig. 10. Ecological-coenotic structure of the average and total number of species of vascular plants on the pit-and-mound microsites: 1, 2 and 3 top, front and back sides of the mound; 4 and 5 pits over and in front of the mound, 6 deadwood, 7 reference plot of $1 \times 1 \mathrm{~m}$. Nm nemoral, Br boreal, Pn piny, Nt nitrophilous, Wt water-marsh, and Md meadow-edge ecological-coenotic species

Changes in vegetation due to the presence of mounds and pits caused by treefalls with uprooting are still rarely a focus of research. Our results showing an increase in the structural and species diversity of vegetation caused by the emergence of new microsites are generally consistent with the results obtained earlier for beech forests of northern Germany [34], coniferous forests dominated by Tsuga canadensis and Pinus strobus in the United States [40] and dark coniferous taiga of the Pechora-Ilych Reserve [36, 37, 64].

\section{Conclusion}

Our research has shown that pit-and-mound microsites formed during massive windthrows contribute to increased diversity of ecologicalcoenotic structure of vegetation of broadleaved forests, promote the emergence of species of boreal, nitrophilous, water-marsh, meadow-edge and piny ecological-coenotic groups of vegetation. The presence of bare substrate on the microsites contributes to the appearance of tree individuals of seed origin for many tree species. The participation of mosses in the ground cover increases significantly. Due to the unique character of polydominant broadleaved forests of the Kaluzhskie Zaseki Reserve it is possible to obtain fundamentally new data on the course of autogenic succession after catastrophic windthrows in the broadleaved forest region. These data and knowledge are important and can help us address the fundamental problems of biodiversity conservation and maintenance of ecosystem sustainability.

\section{Acknowledgements}

The authors express their gratitude to Miroslav Stamenov, Elizaveta Ivanishcheva and Anastasia Mikhaleva for their assistance in collecting field data. Analysis of the field data and the article preparation were carried out within the framework of state assignments of the Institute of Mathematical Problems of Biology of the Russian Academy of Sciences - a branch of M. V. Keldysh Institute of Applied Mathematics of the Russian Academy of Sciences, and the Institute of PhysicoChemical and Biological Problems in Soil Science of the Russian Academy of Sciences (0120-20190005, reg. No. AAA A-A18-118013190176-2). 


\section{Библиографический список}

1. Mitchell, S. J. Wind as a natural disturbance agent in forests: a synthesis / S. J. Mitchell // Forestry. - 2013. Vol. 86. - P. 147-157.

2. Trumbore, S. Forest health and global change / S. Trumbore, P. Brando, H. Hartmann // Science. - 2015. Vol. 349, iss. 6250. - P. 814-818.

3. Thom, D. Natural disturbance impacts on ecosystem services and biodiversity in temperate and boreal forests / D. Thom, R. Seidl // Biol. Rev. - 2016. - Vol. 91. - P. 760-781.

4. Forest disturbances under climate change / R. Seidl, D. Thom, M. Kautz, D. Martin-Benito, M. Peltoniemi, G. Vacchiano et al. // Nature Climate Change. - 2017. - Vol. 7 (6). - P. 395-402.

5. Canham, Ch. D. Catastrophic windthrow in the Presettlement Forests of Wisconsin / Ch. D. Canham, O. L. Loucks // Ecology. - 1984. - Vol. 65, № 3. - P. 803-809.

6. Veblen, T. T. Subalpine forest damage from a severe windstorm in northern Colorado / T. T. Veblen, D. Kulakowski, K. S. Eisenhart, W. L. Baker // Canadian Journal of Forest Research. - 2001. - Vol. 31. P. 2089-2097.

7. Ulanova, N. G. The effects of windthrow on forests at different spatial scales: a review / N. G. Ulanova // Forest Ecology and Management. - 2000. - Vol. 135. - P. 155-167.

8. Tree diversity drives forest stand resistance to natural disturbances / H. Jactel, J. Bauhus, J. Boberg, D. Bonal, B. Castagneyrol, B. Gardiner, J. R. Gonzalez-Olabarria, J. Koricheva, N. Meurisse, E. G. Brockerhoff // Current Forestry Reports. - 2017. - Vol. 3, № 3. - P. 223-243.

9. Дмитриев, Е. А. О происхождении неоднородности почвенного покрова в лесных биогеоценозах / Е. А. Дмитриев, Л. О. Карпачевский, М. Н. Строганова, С. А. Шоба // Проблемы почвоведения. - Москва : Наука, 1978. - С. 212-218.

10. Скворцова, Е. Б. Экологическая роль ветровалов / Е. Б. Скворцова, Н. Г. Уланова, В. Ф. Басевич. - Москва : Лесн. пром-сть, 1983. - 192 с.

11. Schaetzl, R. J. Tree uprooting: review of impacts on forest ecology / R. J. Schaetzl, S. F. Burns, D. L. Johnson, T. W. Small // Vegetatio. - 1989. - Vol. 79. - P. 165-176.

12. Васенев, И. И. Ветровал и таежное почвообразование / И. И. Васенев, В. О. Таргульян. - Москва : Наука, 1995. $-247 \mathrm{c}$.

13. Liechty, H. O. Pit and mound topography and its influence on storage of carbon, nitrogen, and organic matter within an old-growth forest / H. O. Liechty, M. F. Jurgensen, G. D. Mroz, M. R. Gale // Canadian Journal of Forest Research. - 1997. - Vol. 27. - P. 1992-1997.

14. Пономаренко, Е. В. Методические подходы к анализу сукцессионных процессов в почвенном покрове / Е. В. Пономаренко // Сукцессионные процессы в заповедниках России и проблемы сохранения биологического разнообразия / под ред. О. В. Смирновой, Е. С. Шапошникова. - Санкт-Петербург : РБО, 1999.

C. $34-57$.

15. Clinton, B. D. Catastrophic windthrow in the southern Appalachians: characteristics of pits and mounds and initial vegetation responses / B. D. Clinton, C. R. Baker // Forest Ecology and Management. - 2000. - Vol. 126. - P. 51-60.

16. Storms can cause Europe-wide reduction in forest carbon sink / A. Lindroth, F. Lagergren, A. Grelle, L. Klemedtsson, O. Langvall, P. Weslien, J. Tuulik // Global Change Biology. - 2009. - Vol. 15. - P. 346-355.

17. Kooch, Y. Effects of uprooting tree on herbaceous species diversity, woody species regeneration status and soil physical characteristics in a temperate mixed forest of Iran / Y. Kooch, S. M. Hosseini, J. Mohammadi, S. M. Hojjati // Journal of Forestry Research. - 2012. - Vol. 23 (1). - P. 81-86.

18. Kooch, Y. Effects of pits and mounds following windthrow events on soil features and greenhouse gas fluxes in a temperate forest / Y. Kooch, S. M. Darabi, S. M. Hosseini // Pedosphere. - 2015. - Vol. 25 (6). - P. 853-867.

19. Bobrovsky, M. V. Patterns of pedoturbation by tree uprooting in forest soils / M. V. Bobrovsky, S. V. Loyko // Russian Journal of Ecosystem Ecology. - 2016. - Vol. 1 (1). - DOI 10.21685/2500-0578-2016-1-3.

20. Panayotov, K. H. Influence of deadwood on soil carbon, nitrogen, bulk density and $\mathrm{pH}$ in a deciduous nonintervention forest reserve : Masters Thesis / K. H. Panayotov. - 2016. - DOI 10.13140/RG.2.1.1167.7843

21. Impacts of old, comparatively stable, treethrow microtopography on soils and forest dynamics in the northern hardwoods of Michigan, USA / P. Šamonil, M. Valtera, R. J. Schaetzl, D. Adam, I. Vašíčková, P. Daněk, D. Janík, V. Tejnecký // Catena. - 2016. - Vol. 140. - P. 55-65.

22. Yamamoto, S.-I. Forest gap dynamics and tree regeneration / S.-I. Yamamoto // J. For. Res. - 2000. - Vol. 5. P. 223-229.

23. Kuuluvainen, T. Regeneration microsites of Picea abies seedlings in a windthrow area of a boreal old-growth forest in southern Finland / T. Kuuluvainen, R. Kalmari // Annales Botanici Fennici. - 2003. - Vol. 40. - P. 401-413.

24. Ilisson, T. Regeneration development 4-5 years after a storm in Norway spruce dominated forests, Estonia / T. Ilisson, K. Köster, F. Vodde, K. Jögiste // Forest Ecology and Management. - 2007. - Vol. 250. - P. 17-24.

25. Regeneration in windthrow areas in hemiboreal forests: the influence of microsite on the height growths of different tree species / F. Vodde, K. Jõgiste, L. Gruson, T. Ilisson, K. Köster, J. A. Stanturf // Journal of Forest Research. - 2010. - Vol. 15 (1). - P. 55-64. 
26. The influence of storm-induced microsites to tree regeneration patterns in boreal and hemiboreal forest / F. Vodde, K. Jõgiste, Y. Kubota, T. Kuuluvainen, K. Köster, A. Lukjanova, M. Metslaid, T. Yoshida // Journal of Forest Research. - 2011. - Vol. 16 (3). - P. 155-167.

27. Large-scale wind disturbances promote tree diversity in a Central Amazon forest / D. M. Marra, J. Q. Chambers, N. Higuchi, S. E. Trumbore, G. H. P. M. Ribeiro, J. dos Santos, R. I. Negron-Juarez, B. Reu, C. Wirth // PLOS ONE. - 2014. - Vol. 9 (11): e114769.

28. Kathke, S. Gap dynamics in a near-natural spruce forest at Mt. Brocken, Germany / S. Kathke, H. Bruelheide // Forest Ecology and Management. - 2010. - Vol. 259 (3). - P. 624-632.

29. Simon, A. The influence of windthrow microsites on tree regeneration and establishment in an old growth mountain forest / A. Simon, G. Gratzer, M. Sieghardt // Forest Ecology and Management. - 2011. - Vol. 262. P. 1289-1297.

30. Girard, F. Partial windthrow as a driving process of forest dynamics in old-growth boreal forests / F. Girard, L. De Grandpré, J.-C. Ruel // Can. J. For. Res. - 2014. - Vol. 44. - P. 1165-1176.

31. Interaction between tree species populations and windthrow dynamics in natural beech-dominated forest, Czech Republic / B. Šebková, P. Šamonil, M. Valtera, D. Adam, D. Janík // Forest Ecology and Management. - 2012. Vol. 280. - P. 9-19.

32. Pröll, G. Unfavourable microsites, competing vegetation and browsing restrict post-disturbance tree regeneration on extreme sites in the Northern Calcareous Alps / G. Pröll, A. Darabant, G. Gratzer, K. Katzensteiner // European Journal of Forest Research. - 2014. - Vol. 134 (2). - P. 293-308.

33. Effects of gap size and associated changes in light and soil moisture on the understorey vegetation of a Hungarian beech forest / L. Gálhidy, B. Mihók, A. Hagyó, K. Rajkai, T. Standovár // Plant Ecology. - 2006. - Vol. 183. P. 133-145.

34. Oheimb, G. von The effects of windthrow on plant species richness in a Central European beech forest / G. von Oheimb, A. Friedel, A. Bertsch, W. Härdtle // Plant Ecol. - 2007. - Vol. 191. - P. 47-65.

35. Nowinska, R. Reactions of the herb and moss layer, tree saplings and the shrub layer to tree deaths in forests of the Wielkopolska National Park (Western Poland) / R. Nowinska // Biologia. Section Botany. - 2010. - Vol. 65 (2). P. 265-272. - DOI 10.2478/s11756-010-0014-X

36. Запрудина, М. В. Микромозаичная организация травяно-кустарничкового и мохового покрова среднетаежных темнохвойных лесов Урала : дис. ... канд. биол. наук / Запрудина М. В. - Москва : МПГУ, 2012. $-204 \mathrm{c}$.

37. Микромозаичная организация и фитомасса напочвенного покрова в основных типах темнохвойных лесов Печоро-Илычского заповедника / Д. Л. Луговая, О. В. Смирнова, М. В. Запрудина, А. А. Алейников, В. Э. Смирнов // Экология. - 2013. - № 1. - С. 1-8.

38. Kern, C. C. Canopy gap size influences niche partitioning of the ground-layer plant community in a northern temperate forest / C. C. Kern, R. A. Montgomery, P. B. Reich, T. F. Strong // Journal of Plant Ecology. - 2013. Vol. 6, № 1. - P. 101-112.

39. Quantifying the impact of an extreme climate event on species diversity in fragmented temperate forests: the effect of the October 1987 storm on British broadleaved woodlands / S. M. Smart, A. M. Ellison, R. G. H. Bunce, R. H. Marrs, K. J. Kirby, A. Kimberley, A. W. Scott, D. R. Foster // Journal of Ecology. - 2014. - Vol. 102. P. 1273-1287.

40. Long-term influence of disturbance-generated microsites on forest structural and compositional development / E. M. Sass, A. W. D’Amato, D. R. Foster, A. B. Plotkin, S. Fraver, P. K. Schoonmaker, D. A. Orwig // Can. J. For. Res. - 2018. - Vol. 48. - P. 958-965.

41. Chećko, E. The importance of coarse woody debris for vascular plants in temperate mixed deciduous forests / E. Chećko, B. Jaroszewicz, K. Olejniczak, A. J. Kwiatkowska-Falińska // Canadian Journal of Forest Research. 2015. - Vol. 45 (9). - P. 1154-1163.

42. Chmura, D. Interactions between plant traits and environmental factors within and among montane forest belts: A study of vascular species colonising decaying logs / D. Chmura, J. Żarnowiec, M. Staniaszek-Kik // Forest Ecology and Management. - 2016. - Vol. 379. - P. 216-225.

43. Unar, P. The colonization of decaying logs by vascular plants and the consequences of fallen logs for herb layer diversity in a lowland alluvial forest / P. Unar, D. Janík, D. Adam, M. Vymazalová // European Journal of Forest Research. - 2017. - Vol. 136, № 4. - P. 665-676.

44. Растительность Европейской части СССР / под ред. С. А. Грибовой, Т. И. Исаченко, Е. М. Лавренко. Ленинград : Наука, 1980. - $431 \mathrm{c.}$

45. Яковлев, А. И. Засечная черта Московского государства в XVII веке / А. И. Яковлев. - Москва : Тип. Г. Лисснера и Д. Собко, 1916. - 312 с.

46. Сукцессионные процессы в заповедниках России и проблемы сохранения биологического разнообразия / Р. В. Попадюк, О. В. Смирнова, Л. Б. Заугольнова, Л. Г. Ханина, М. В. Бобровский, Т. О. Яницкая ; под ред. О. В. Смирновой, Е. С. Шапошникова. - Санкт-Петербург : Российское ботаническое общество, - 1999. C. 58-105.

47. Бобровский, М. В. Козельские засеки (эколого-исторический очерк) / М. В. Бобровский. - Калуга : Изд-во Н. Бочкаревой, 2002. - 92 с. 
48. Бобровский, М. В. Оценка и сохранение биоразнообразия лесного покрова в заповедниках Европейской России / М. В. Бобровский, Л. Г. Ханина ; под ред. Л. Б. Заугольновой. - Москва : Научный мир, 2000. С. $104-124$.

49. Справочник по климату CССР. - Ленинград : Гидрометоиздат, 1967. - Вып. 8, часть IV. Влажность воздуха, атмосферные осадки и снежный покров.

50. Бобровский, М. В. Катастрофический ветровал 2006 года на территории заповедника «Калужские засеки»/ М. В. Бобровский, М.Н.Стаменов // Лесоведение. - 2019. - № 4.

51. Заугольнова, Л. Б. Анализ ассоциаций мезофитных широколиственных лесов в центре Европейской России / Л. Б. Заугольнова, Т. Ю. Браславская // Растительность России. - 2003. - № 4. - С. 3-28.

52. McCune, B. PC-ORD. Multivariate Analysis of Ecological Data / B. McCune, M. J. Mefford. - Gleneden Beach, Oregon, U.S.A. : MjM Software, 2011. - Version 6.21.

53. Hill, M. O. DECORANA--a FORTRAN program for detrended correspondence analysis and reciprocal averaging / M. O. Hill. - Ithaca, NY. : Ecology and Systematics, Cornell University, 1979.

54. Flora indicativa = Ecological Indicator Values and Biological Attributes of the Flora of Switzerland and the Alps / E. Landolt, B. Bäumler, A. Erhardt, O. Hegg, F. Klötzli, W. Lämmler, M. Nobis, K. Rudmann-Maurer, F. H. Schweingruber, J.-P. Theurillat, E. Urmi, M. Vust, T. Wohlgemuth. - Bern : Haupt-Verlag, 2010. - 376 p.

55. Ханина, Л. Г. Новые возможности программы Ecoscale для обработки геоботанических описаний по экологическим шкалам / Л. Г. Ханина, Т. И. Грохлина, Е. М. Глухова // Математическая биология и биоинформатика : докл. V Междунар. конф. - Москва : Макс Пресс, 2014. - С. 192-193.

56. Информационно-аналитическая система для оценки сукцессионного состояния лесных сообществ / Л. Б. Заугольнова, Л. Г. Ханина, А. С. Комаров, О. В. Смирнова, Р. В. Попадюк, М. А. Островский, Е. В. Зубкова, Е. М. Глухова, М. М. Паленова, В. С. Губанов, П. Я. Грабарник. - Пущино : ОНТИ ПНЦ РАН, 1995. $-51 \mathrm{c}$.

57. Смирнова, О. В. Эколого-ценотические группы в растительном покрове лесного пояса Восточной Европы. Восточно-Европейские леса (история в голоцене и современность) / О. В. Смирнова, Л. Г. Ханина, В. Э. Смирнов. - Москва : Наука, 2004. - Т. 1. - С. 165-175.

58. Смирнов, В. Э. Обоснование системы эколого-ценотических групп растений лесной зоны Европейской России на основе экологических шкал, геоботанических описаний и статистического анализа / В. Э. Смирнов, Л. Г. Ханина, М. В. Бобровский // Бюллетень Московского общества испытателей природы. Отдел биологический. - 2006. - Т. 111, № 2. - С. 36-47.

59. Смирнов, В. Э. Расширенная система эколого-ценотических групп видов сосудистых растений для бореальной, гемибореальной и умеренной лесных зон Европейской России / В. Э. Смирнов, Л. Г. Ханина, М. В. Бобровский. - 2008. - URL: http://www.impb.ru/index.php?id=div/lce/ecg (дата обращения: май 2019).

60. Dufrêne, M. Species assemblages and indicator species: The need for a flexible asymmetrical approach / M. Dufrêne, P. Legendre // Ecological Monographs. - 1997. - Vol. 67. - P. 345-366.

61. Whittaker, R. H. Evolution and measurement of species diversity / R. H. Whittaker // Taxon. - 1972. - Vol. 21. P. 213-251.

62. Khanina, L. G. Temperate Forests of European Russia / L. G. Khanina, M. V. Bobrovsky // European Vegetation Archive. - Ref. number EU-RU-014. - URL: https://www.givd.info/ID/EU-RU-014 (дата обращения: май 2019).

63. Бобровский, М. В. Лесные почвы европейской России. Биотические и антропогенные факторы формирования / М. В. Бобровский. - Москва : Товарищество научных изданий КМК, 2010. - 392 с.

64. Boreal forests / O. V. Smirnova, M. V. Bobrovsky, L. G. Khanina, L. B. Zaugolnova, V. N. Korotkov, A. A. Aleynikov, O. I. Evstigneev, V. E. Smirnov, N. S. Smirnov, M. V. Zaprudina // European Russian forests. Their current state and features of their history. - Springer Netherlands, 2017. - P. 63-208. - DOI 10.1007/978-94-024$1172-3$.

\section{References}

1. Mitchell S. J. Forestry. 2013, vol. 86, pp. 147-157.

2. Trumbore S., Brando P., Hartmann H. Science. 2015, vol. 349, iss. 6250, pp. 814-818.

3. Thom D., Seidl R. Biol. Rev. 2016, vol. 91, pp. 760-781.

4. Seidl R., Thom D., Kautz M., Martin-Benito D., Peltoniemi M., Vacchiano G. et al. Nature Climate Change. 2017, vol. 7 (6), pp. 395-402.

5. Canham Ch. D., Loucks O. L. Ecology. 1984, vol. 65, no. 3, pp. 803-809.

6. Veblen T. T., Kulakowski D., Eisenhart K. S., Baker W. L. Canadian Journal of Forest Research. 2001, vol. 31, pp. 2089-2097.

7. Ulanova N. G. Forest Ecology and Management. 2000, vol. 135, pp. 155-167.

8. Jactel H., Bauhus J., Boberg J., Bonal D., Castagneyrol B., Gardiner B., Gonzalez-Olabarria J. R., Koricheva J., Meurisse N., Brockerhoff E. G. Current Forestry Reports. 2017, vol. 3, no. 3, pp. 223-243.

9. Dmitriev E. A., Karpachevskiy L. O., Stroganova M. N., Shoba S. A. Problemy pochvovedeniya [Problems of soil studies]. Moscow: Nauka, 1978, pp. 212-218. [In Russian]

10. Skvortsova E. B., Ulanova N. G., Basevich V. F. Ekologicheskaya rol' vetrovalov [Ecological role of windfalls]. Moscow: Lesn. prom-st', 1983, 192 p. [In Russian] 
11. Schaetzl R. J., Burns S. F., Johnson D. L., Small T. W. Vegetation. 1989, vol. 79, pp. 165-176.

12. Vasenev I. I., Targul'yan V. O. Vetroval $i$ taezhnoe pochvoobrazovanie [Windfall and taiga soil formation]. Moscow: Nauka, 1995, 247 p. [In Russian]

13. Liechty H. O., Jurgensen M. F., Mroz G. D., Gale M. R. Canadian Journal of Forest Research. 1997, vol. 27, pp. 1992-1997.

14. Ponomarenko E. V. Suktsessionnye protsessy v zapovednikakh Rossii i problemy sokhraneniya biologicheskogo raznoobraziya [Successional processes in Russian nature reserves and problems of maintaining biological diversity]. Saint-Petersburg: RBO, 1999, pp. 34-57. [In Russian]

15. Clinton B. D., Baker C. R. Forest Ecology and Management. 2000, vol. 126, pp. 51-60.

16. Lindroth A., Lagergren F., Grelle A., Klemedtsson L., Langvall O., Weslien P., Tuulik J. Global Change Biology. 2009, vol. 15, pp. 346-355.

17. Kooch Y., Hosseini S. M., Mohammadi J., Hojjati S. M. Journal of Forestry Research. 2012, vol. 23 (1), pp. 81-86.

18. Kooch Y., Darabi S. M., Hosseini S. M. Pedosphere. 2015, vol. 25 (6), pp. 853-867.

19. Bobrovsky M. V., Loyko S. V. Russian Journal of Ecosystem Ecology. 2016, vol. 1 (1). DOI 10.21685/25000578-2016-1-3.

20. Panayotov K. H. Influence of deadwood on soil carbon, nitrogen, bulk density and pH in a deciduous nonintervention forest reserve: Masters Thesis. 2016. DOI 10.13140/RG.2.1.1167.7843

21. Šamonil P., Valtera M., Schaetzl R. J., Adam D., Vašíčková I., Daněk P., Janík D., Tejnecký V. Catena. 2016, vol. 140, pp. 55-65.

22. Yamamoto S.-I. J. For. Res. 2000, vol. 5, pp. 223-229.

23. Kuuluvainen T., Kalmari R. Annales Botanici Fennici. 2003, vol. 40, pp. 401-413.

24. Ilisson T., Köster K., Vodde F., Jögiste K. Forest Ecology and Management. 2007, vol. 250, pp. 17-24.

25. Vodde F., Jõgiste K., Gruson L., Ilisson T., Köster K., Stanturf J. A. Journal of Forest Research. 2010, vol. 15 (1), pp. 55-64.

26. Vodde F., Jõgiste K., Kubota Y., Kuuluvainen T., Köster K., Lukjanova A., Metslaid M., Yoshida T. Journal of Forest Research. 2011, vol. 16 (3), pp. 155-167.

27. Marra D. M., Chambers J. Q., Higuchi N., Trumbore S. E., Ribeiro G. H. P. M., J. dos Santos, Negron-Juarez R. I., Reu B., Wirth C. PLOS ONE. 2014, vol. 9 (11): e114769.

28. Kathke S., Bruelheide H. Forest Ecology and Management. 2010, vol. 259 (3), pp. 624-632.

29. Simon A., Gratzer G., Sieghardt M. Forest Ecology and Management. 2011, vol. 262, pp. 1289-1297.

30. Girard F., L. De Grandpré, Ruel J.-C. Can. J. For. Res. 2014, vol. 44, pp. 1165-1176.

31. Šebková B., Šamonil P., Valtera M., Adam D., Janík D. Forest Ecology and Management. 2012, vol. 280, pp. 919.

32. Pröll G., Darabant A., Gratzer G., Katzensteiner K. European Journal of Forest Research. 2014, vol. 134 (2), pp. 293-308.

33. Gálhidy L., Mihók B., Hagyó A., Rajkai K., Standovár T. Plant Ecology. 2006, vol. 183, pp. $133-145$.

34. Oheimb G. von, Friedel A., Bertsch A., Härdtle W. Plant Ecol. 2007, vol. 191, pp. 47-65.

35. Nowinska R. Biologia. Section Botany. 2010, vol. 65 (2), pp. 265-272. DOI 10.2478/s11756-010-0014-x

36. Zaprudina M. V. Mikromozaichnaya organizatsiya travyano-kustarnichkovogo $i$ mokhovogo pokrova srednetaezhnykh temnokhvoynykh lesov Urala: dis. kand. biol. nauk [Micromosaic organization of grass bush and moss cover of middle taiga dark coniferous forests of the Urals: thesis of the cand. of biol. sciences]. Moscow: MPGU, 2012, 204 p. [In Russian]

37. Lugovaya D. L., Smirnova O. V., Zaprudina M. V., Aleynikov A. A., Smirnov V. E. Ekologiya [Ecology]. 2013, no. 1, pp. 1-8.

38. Kern C. C., Montgomery R. A., Reich P. B., Strong T. F. Journal of Plant Ecology. 2013, vol. 6, no. 1, pp. 101112.

39. Smart S. M., Ellison A. M., Bunce R. G. H., Marrs R. H., Kirby K. J., Kimberley A., Scott A. W., Foster D. R. Journal of Ecology. 2014, vol. 102, pp. 1273-1287.

40. Sass E. M., D’Amato A. W., Foster D. R., Plotkin A. B., Fraver S., Schoonmaker P. K., Orwig D. A. Can. J. For. Res. 2018, vol. 48, pp. 958-965.

41. Chećko E., Jaroszewicz B., Olejniczak K., Kwiatkowska-Falińska A. J. Canadian Journal of Forest Research. 2015, vol. 45 (9), pp. 1154-1163.

42. Chmura D., Żarnowiec J., Staniaszek-Kik M. Forest Ecology and Management. 2016, vol. 379, pp. $216-225$.

43. Unar P., Janík D., Adam D., Vymazalová M. European Journal of Forest Research. 2017, vol. 136, no. 4, pp. 665-676.

44. Rastitel'nost' Evropeyskoy chasti SSSR [Vegetation of the European part of the USSR]. Eds. S. A. Gribova, T. I. Isachenko, E. M. Lavrenko. Leningrad: Nauka, 1980, 431 p. [In Russian]

45. Yakovlev A. I. Zasechnaya cherta Moskovskogo gosudarstva v XVII veke [The marked line of the Moscow State in the $17^{\text {th }}$ century]. Moscow: Tip. G. Lissnera i D. Sobko, 1916, 312 p. [In Russian]

46. Popadyuk R. V., Smirnova O. V., Zaugol'nova L. B., Khanina L. G., Bobrovskiy M. V., Yanitskaya T. O. Suktsessionnye protsessy $v$ zapovednikakh Rossii $i$ problemy sokhraneniya biologicheskogo raznoobraziya 
[Successional processes in Russian nature reserves and problems of maintaining biological diversity]. SaintPetersburg: Rossiyskoe botanicheskoe obshchestvo, 1999, pp. 58-105. [In Russian]

47. Bobrovskiy M. V. Kozel'skie zaseki (ekologo-istoricheskiy ocherk) [Kozel forest reserve (ecological and historical review)]. Kaluga: Izd-vo N. Bochkarevoy, 2002, 92 p. [In Russian]

48. Bobrovskiy M. V., Khanina L. G. Otsenka i sokhranenie bioraznoobraziya lesnogo pokrova v zapovednikakh Evropeyskoy Rossii [Assessing and maintaining biological diversity of forest cover in nature reserves of the European Russia]. Moscow: Nauchnyy mir, 2000, pp. 104-124. [In Russian]

49. Spravochnik po klimatu SSSR [Guidebook of the USSR climate]. Leningrad: Gidrometoizdat, 1967, iss. 8, part IV. [In Russian]

50. Bobrovskiy M. V., Stamenov M. N. Lesovedenie [Forest science]. 2019, no. 4. [In Russian]

51. Zaugol'nova L. B., Braslavskaya T. Yu. Rastitel'nost' Rossii [Vegetation of Russia]. 2003, no. 4, pp. 3-28. [In Russian]

52. McCune B., Mefford M. J. PC-ORD. Multivariate Analysis of Ecological Data. Gleneden Beach, Oregon, U.S.A.: MjM Software, 2011, Version 6.21.

53. Hill M. O. DECORANA--a FORTRAN program for detrended correspondence analysis and reciprocal averaging. Ithaca, New York: Ecology and Systematics, Cornell University, 1979.

54. Landolt E., Bäumler B., Erhardt A., Hegg O., Klötzli F., Lämmler W., Nobis M., Rudmann-Maurer K., Schweingruber F. H., Theurillat J.-P., Urmi E., Vust M., Wohlgemuth T. Flora indicativa = Ecological Indicator Values and Biological Attributes of the Flora of Switzerland and the Alps. Bern: Haupt-Verlag, 2010, 376 p.

55. Khanina L. G., Grokhlina T. I., Glukhova E. M. Matematicheskaya biologiya i bioinformatika: dokl. V Mezhdunar. konf. [Mathematical biology and bioinformatics: proceedings of the $5^{\text {th }}$ International Conference]. Moscow: Maks Press, 2014, pp. 192-193. [In Russian]

56. Zaugol'nova L. B., Khanina L. G., Komarov A. S., Smirnova O. V., Popadyuk R. V., Ostrovskiy M. A., Zubkova E. V., Glukhova E. M., Palenova M. M., Gubanov V. S., Grabarnik P. Ya. Informatsionno-analiticheskaya sistema dlya otsenki suktsessionnogo sostoyaniya lesnykh soobshchestv [Information and analytical system for assessing successional state of forest communities]. Pushchino: ONTI PNTs RAN, 1995, 51 p. [In Russian]

57. Smirnova O. V., Khanina L. G., Smirnov V. E. Ekologo-tsenoticheskie gruppy v rastitel'nom pokrove lesnogo poyasa Vostochnoy Evropy. Vostochno-Evropeyskie lesa (istoriya v golotsene i sovremennost') [Ecological and cenotic groups in vegetation cover of the forest zone in Eastern Europe. Eastern European forests]. Moscow: Nauka, 2004, vol. 1, pp. 165-175. [In Russian]

58. Smirnov V. E., Khanina L. G., Bobrovskiy M. V. Byulleten' Moskovskogo obshchestva ispytateley prirody. Otdel biologicheskiy [Bulletin of Moscow Society of Naturalists. Biological series]. 2006, vol. 111, no. 2, pp. 36-47. [In Russian]

59. Smirnov V. E., Khanina L. G., Bobrovskiy M. V. Rasshirennaya sistema ekologo-tsenoticheskikh grupp vidov sosudistykh rasteniy dlya boreal'noy, gemiboreal'noy $i$ umerennoy lesnykh zon Evropeyskoy Rossii [Extended system of ecological and cenotic groups of vascular plants species for boreal, hemiborean and temperate forest zones of European Russia]. 2008. Available at: http://www.impb.ru/index.php?id=div/lce/ecg (accessed May 2019). [In Russian]

60. Dufrêne M., Legendre P. Ecological Monographs. 1997, vol. 67, pp. 345-366.

61. Whittaker R. H. Taxon. 1972, vol. 21, pp. 213-251.

62. Khanina L. G., Bobrovsky M. V. European Vegetation Archive. - Ref. number EU-RU-014. Available at: https://www.givd.info/ID/EU-RU-014 (accessed May 2019).

63. Bobrovskiy M. V. Lesnye pochvy evropeyskoy Rossii. Bioticheskie i antropogennye faktory formirovaniya [Forest soils of European Russia. Biotic and anthropogenic factors of formation]. Moscow: Tovarishchestvo nauchnykh izdaniy KMK, 2010, 392 p. [In Russian]

64. Smirnova O. V., Bobrovsky M. V., Khanina L. G., Zaugolnova L. B., Korotkov V. N., Aleynikov A. A., Evstigneev O. I., Smirnov V. E., Smirnov N. S., Zaprudina M. V. European Russian forests. Their current state and features of their history. Springer Netherlands, 2017, pp. 63-208. DOI 10.1007/978-94-024-1172-3. 